\title{
Refocusing Technical Teachers' Education Programmes towards Youth Empowerment
}

\author{
Suleiman Abdulwahab ${ }^{1}$, Haruna Rasheed Sa'i ${ }^{2}$ \\ ${ }^{l}$ school Of Technical Education, Fce (T) Gombe, Nigeria \\ ${ }^{2}$ kaduna Polytechnic
}

\begin{abstract}
Inspite of various governments' efforts to combat the social menace of unemployed youths, the rate of unemployment is still on the increase in Nigeria. It is as if the system has defiled all developmental principles and theories that have worked perfectly well in other countries. This paper sees technical teachers' education programmes as possessing the potent power of transforming the Nigerian society to a greater height if properly planned and executed. Consequently, the paper exposes the major lapses in the planning and organization of technical teachers' education programmes and suggests strategies for their improvement. It was concluded that unless these programmes are refocused towards youths empowerment, the bitter stories of underdevelopment have just stared in Nigeria literature.
\end{abstract}

Keywords: Refocusing, Technical Teacher, Education Programmes, Youth Empowerment

\section{Introduction}

Fifty years after political independence, Nigeria has not attained tangible technological breakthrough, economic emancipations, agricultural sustainability and social stability. This assertion according to Bamidele (2002) becomes apparent when one looks at the country's overdependence on importation of manufactured products, importation of food items including fertilizers, reliability on foreign aids and loans, high rate of unemployment and the perennial security problems. Many educationists have advanced several reasons for the Nigeria contemporary state of imbroglio. Tafida and Abdulwahab (2010) attributed it to poor leadership, haphazard policies, poor planning, corruption, indiscipline, lack of accountability and above all flimsy implementation of educational programmes.

Technical education programmes are severely and negatively affected when poorly implemented since the training of the teachers requires the use of machines, equipment and tools, as well as constant supply of consumables for practical activities. Adequate workshop experiences are paramount to this group of teachers if they are to impart appropriate practical skills to the younger ones as envisaged in the National Policy on Education (FGN, 2004). The way and manner the technical teachers' education programmes are managed will eventually have spontaneous effects on the quality of their products and the overall technological advancement of the Nation. Since the products of these programmes constitute a significant proportion of the teaming youth of the country, the incidence of unemployment among the youth will continuous to multiply, which in earnest may give rise to social insecurity as we are now witnessing. It is against this background that the need to refocus the technical teachers' education programmes towards youth empowerment becomes highly imperative. To refocus is to change the emphasis or direction of something. Technical teachers' education programmes need to re-emphasize acquisition of manipulative skills.

\section{Youth Empowerment}

The phrase 'youth empowerment' amalgamates two important words (Youth and Empowerment). The United Nations, for statistical purposes, defines youth as those persons between the ages of 15 and 24 years without prejudice to other definitions by member States. Youth is an age of adventure; it is a bridge between the adolescent and the adult or old age. Characteristically, the youth has his body and soul intact; the teeth can cut, the hands are strong and the knees are always ready, while the brain and eyes are photogenic. Behaviorally, the youth is full of vigor and pride. It is indeed, the most useful stage of one's life (Isa and Abdulkadir, 2012).

Empowerment is the process of increasing the capacity of individuals or group to make choices and transform these choices into desired actions and outcomes. It also includes encouraging and developing the skills for self-sufficiency, with a focus on eliminating future need for charity or welfare in the individual or group (Akande, 2010). In essence, empowerment speaks to self determined change. It implies bringing together the supply and demand within which poor people live and helping them build and capitalize on their own attributes (World Bank, 2011). Empowerment cuts across education and health-care to governance and economic policy. Activities which seek to empower poor people are expected to increase development 
opportunities, enhance development outcomes and improve people quality of life. Empowered people have freedom of choice and actions. This in turn enables them to better influence the course of their lives and the decisions which affect them.

Youth empowerment is defined by the Youth Empowerment Solution (YES, 2011) as the outcome by which youth as change agent, gain the skills to impact their own lives and lives of other individuals, organizations and communities. Generally youth empowerment is understood as the means through which the youth are encouraged financially, skillfully, academically, agriculturally and morally. Youth empowerment has become refrain of the Nigerian elites at various fora. It is a recurring decimal as well on the planning tables and discussions of the governments at various levels and among the highly placed members of Nigerian society. It reveals the self consciousness of the government about the youth and the need to bake them early enough for the progress and development of the society. Therefore, no serious country could afford to toy with youth empowerment (Akande, 2010). President Obasanjo, once said, youth are the future and any nation or community which jokes with its future is doomed (Olukoya, 2014).

\section{Technical Teachers' Education Programmes in Nigeria}

Technical teachers' education programmes are types of programmes that are specifically set-up for the training and preparation of teachers in various subjects relating to technology such as metalwork technology, electrical/electronic technology, building construction technology, automobile technology and woodwork technology. Okoro (2006) described the technical teacher education as consisting of three basic components. These are the technical education component, professional education component and general education component. In Nigeria, technical teachers' education programmes are run at different levels of education and are controlled by different bodies or agencies. They are categorized as follows;-

i Colleges of Education technical education programmes are controlled by the National Commission for Colleges of Education (NCCE). The graduates are awarded the Nigerian Certificate in Education (NCE) Technical. This certificate is now regarded as the minimum teaching qualification in Nigeria. NCE technjcal programmes are expected to prepare competent technical teachers that are capable of imparting basic technology knowledge and skills to junior secondary school students (NCCE, 2012).

ii The Bachelor of Technology Education programmes are run in Universities of Technology and some Polytechnics under the auspices of National University Commission (NUC). These programmes lead to the award of bachelor degree in technology education (B,Tech Ed) and prepare technology teachers competently fit to teach vocational or trade subjects such as metalwork, electronics, building construction and woodwork at senior secondary schools level (FGN, 2004). They are equally expected to effectively teach technical courses in Colleges of Education (Technical).

iii The post-graduate technical teachers education programmes which lead o the award of Master and Doctoral Degrees in technology education M. Tech Ed and Ph.D Industrial respectively. They are offered in Nigerian Universities and are controlled by the NUC. The programmes are meant to produce technology teachers for College of Education, Polytechnics and Universities that run technical teachers training programmes.

iv The Post-Graduate Diploma in Education (PGDE) programme is mounted in Universities and is meant to give one year to two years professional education training to engineers and technologists who might have graduated from the universities or polytechnics and are willing to take up teaching job.

The above existing categories of technical teachers' education programmes form the basis for the classification of technical teachers in some studies or literature in Nigeria. The first three categories which are NCE Tech, B.Tech Ed, M.Tech Ed and Ph.D Tech are the so called professionally trained technical teachers. The forth category which are the engineers and technologists with PGDE are classified as the unprofessionally trained technical teachers. This dichotomy is often used to compare technical teachers' opinion in studies relating to students' performance and teachers' competencies. (Apagu, 1997; Dirazo, 2000 and Idris, 2006).

Available literature (Jadas, 1999: Abdulwahab, 2004: Okoro, 2006 and ogwa, 2012) have shown that the so called professionally trained technical teachers are good in teaching concepts and imparting knowledge but lack adequate manipulative skills in their field of technology. Whereas, the other group (unprofessionally trained) are described as having better possession of manipulative skills and deeper technical knowledge in their field of specialization but deficient in teaching techniques, methods, attitudes and commitment to impart the knowledge and skills. This group of technical teachers has also been identified for quitting the teaching job at the slightest opportunity (Udo, 2012).

The scenario above uncovers the major setback in the preparation and training of technical teachers in Nigeria which spontaneously affects the training of youths for self-employment. Unless this issues is strategically resolved, the rate of unemployment shall continue to multiply by time. 


\section{Lapses of Technical Teachers' Education Programmes in Nigeria}

The need to re-focus the technical teachers' education programmes becomes apparent as a result of general outcry of many educationists, researchers, industrialists, as well as beneficiaries of the programs over the relevance and suitability of the programs curriculum contents to the contemporary Nigerian society. Olaitan (1996), Jaddas (1999), Abdulwahab (2004) and Okoro, (2006).

Eminent educationists, Olaitan (1996), Nuru (2002), Okoro (2006) and Victor (2009) have over the years called for more purposeful and realistic objectives of technical education programs that will make the beneficiaries real practitioner of technology. It is only when this is achieved that the teachers can transform the society technologically. Major lapses in the existing technical teachers training programmes are discussed below:

* Inability of the programmes to provide its receipeints with relevant skills suitable for effective teaching at any level of technical education institutions. In connection with this, Alabura (2001) maintained that it is unfortunate that the existing programs of technical teacher education and training in Nigeria have by and large failed to prepare the kinds of professional teachers needed in our schools and colleges. They do not only lack adequate preparation for teaching techniques in schools but are frequently deficient also in basic specialized subject skill.

* In consonance with this was the lamentation of the executive secretary of the NCCE that the NCE curriculum failed to disseminate the requisite knowledge and skills for efficient teaching. He draws his inference from the research conducted by the commission during the classroom interaction in primary and junior secondary schools (Maureen, 2010).

- The NCE technical education curriculum which was designed to prepare teachers for effective teaching of technology at the Junior Secondary School level could not address the problem of dropouts that are expected to acquire a trade for survival. This is because the teachers lack specific vocation talk less of transferring it to the younger ones. In a study conducted by Haruna (2012), it was discovered that NCE technical education curriculum is neither relevant nor adequate for teaching certain aspects of basic technology, such as plumbing, rural and urban water supply, plastic and rubber works, ceramic work and food technology. His findings might not be unconnected with the relative limited credit units accorded to technical courses in the curriculum.

* The technical teachers' degree progrmme is also unsuitable for effective teaching of trade courses in senior secondary schools and technical colleges. Kenedy (2011) observed great dissimilarities in the curriculum contents of technical colleges and that of universities. Under this condition, the graduates of bachelor of technology education programme may not directly fit to teach in technical colleges. Also, one would expect the masters of technology education programme to prepare teachers that will fit well in College of Education (Technical) and |Polytechnics. This is not so as the curriculum contents were equally not married together.

* The curriculum is doped with more courses in education and general studies than the desired technical knowledge and skills. This single factor is strong enough to call for a curriculum review of technical education programmes as it is one of the factors responsible for the students' disengagement with the programmes. In line with this, Ali (2000) observed that the professional education contents of technical education curricular are overemphasized. It seems that emphases are placed on the ability to teach rather than acquisition of technical knowledge and skills. This assertion is in conformity with the findings of a correlation study conducted by Tafida (2002) on students' performance in education courses and major technical courses. It was discovered that there was a significant difference in favour of education courses in students' performance. He attributed his finding to excessive number of credit units allocated to education courses in the technical education curricular since students will have ample time with little course contents to cover.

* Curriculum contents are not competency based and specific. A careful study of the technical teachers' education curriculum at all levels reveals that the depth of contents coverage is left at the discretion of teachers' expertise and commitment. One would expect the curriculum to spell out in clear terms teachers' and students' activities for a specified course contents as obtainable in the National Board for Technical Education (NBTE) curriculum modules. This will provide a platform on which the assessment and evaluation of students' outcomes can be based. It will also give an insight on the materials needed for students' activities.

* Inability of the program to provide their recipients with concrete vocational skills for self-reliance. Over the years, many beneficiaries of the technical teachers' education programmes have showed their discontentment on the inability of programs in equipping them with saleable skills or trade (Jadas, 1999 \& Abdulwahab, 2004). One would expect the graduates of the programmes to be able to demonstrate expertise in a related or particular vocation within their area of specialization. For instance those who study electricity/electronics to possess skills in vocations like Radio and TV repairs, Computer hardware 
maintenance, Electrical machines repairs; Fridge and air condition repairs, Computer networking and so on. Victor (2009) describes the defect in technical and vocational education in Nigeria. Thus, it is unfortunate to discover that the recipients of technical and vocational education in Nigeria are also among the unemployed youths. This is an indication of great defect in planning and implementation of technical teacher education programmes. A teacher who cannot demonstrate expertise in manipulative skills can hardly give a trade to the younger ones.

* The programs are out of phase with the aspiration and needs of their recipients. Majority of the trained technical teachers will discourage their wards from passing through the same system. This is not because of the low remuneration associated with the teaching profession but for lack of satisfaction with the experiences provided by the program. In a follow-up study conducted by Jadas (1999) on the Bachelor of Education (Technology) graduates, it was discovered among others that the graduates were dissatisfied with some of the instructional provisions and that the programs felt short of desired expectations.

* The programs do not provide rooms for staff industrial experience. All technical teachers education programs should embrace the need for staff industrial experience. This can be achieved through deliberate inclusion of teaching and non-teaching staff in industrial training. This will boost the staff practical experiences and will enable them update their knowledge in newer areas of human endeavors with a view to sharing their experiences with their students and colleagues

\section{Strategies for the Improvement of Technical Teachers' Education Programmes}

The lapses so far identified with the Nigerian technical teachers' education programs are capable of frustrating any government's effort towards poverty alleviation, unemployment reduction, security plans and technology advancement. It is therefore necessary to re-focus the programs in a way that will equip the recipients with saleable skills that can be transferred to the younger ones. In line with this, the following strategies are suggested:

i Reviewing the objectives of each program: The objectives of each technical teachers' education programme need to be re-stated in focus of a particular level of practice for its beneficiaries. The level at with the preservice teachers will practice should be clearly and vividly spell out in the programme objectives.

ii Reconciling the curriculum contents for training of teachers to that of their expected students. This will facilitate smooth transitions of teachers from trainees to trainers.

iii Adopting the competency based curriculum. The curriculum contents of the technical teachers' education programmes need to be re-designed to conform with the current curriculum innovations that provide rooms for teachers' assessment and individualized learning. Under a particular content, the tasks of the teachers and students' activities should be clearly stated. It is when this is done that one can confidently ascertain whether these teachers have justified their earnings.

iv Elimination of too numerous educational and general studies contents. The technical teachers' education curriculum should be refocused to contain deeper coverage of technical contents and skills in area of specialization. More room should be provided for workshop practice. The professional contents can be splited over the duration of the programme in smaller units while the general studies contents should by drastically minimized. If I have the chance, I would suggest 60:30:10 for technical, professional and general studies contents, respectively.

$\mathrm{v}$ Inclusion of related vocations within the curriculum of technical teachers' education programs. It is necessary to incorporate some vocations alongside with the technical teachers curricular. For instance, a student teacher majoring in automobile technology may also learn related vocations such as panel beating, auto electricity, engine repairs and maintenance, alignment system and so on. Provision of technical services should also be incorporated or carried out in all workshops so that little fund can be generated to complement government's efforts in the provision of consumable materials for students' practical.

vi Legalization of staff industrial experience. Technical teachers education programs need to be refocused so as to emphasize staff industrial works experience scheme. This will assist in updating the knowledge and manipulative skills of teaching and non teaching staff in a given department. Staff can be sent to special areas of interest that are related to their areas of study in public and private sectors with the view of acquiring necessary skills in a vocation. This skills can later be transferred to colleagues and students which in turn will go along way in transforming the entire society.

\section{Conclusion}

Looking at the current state of Nigerian society in terms of underdevelopment, economic crisis, corruption, unemployment and the perennial insecurity and the role of technical teachers' education in the transformation and uplifting of any society, the government has no option other than to refocus its technical teachers' education programmes. 


\section{References}

[1]. Abdulwahab, S. (2004). Follow-up study of technical education graduates of FederalColleges of Education (Technical) in Northeastern States of Nigeria. M, Ed Tech. Dissertation. University of Nigeria, Nsukka.

[2]. Akande, T.T (2010). Youth empowerment and technical and vocational education and training

(TVET) in Nigeria. Being a lead paper delivered at the 23rd annual conference of NATT. Ifyo; Nigeria.

[3]. Alabura, F.A (2001). The professional teachers and quality of teacher education and training: Nigeria perspective. A lead paper delivered at the $3^{\text {rd }}$ National Seminal Organised by League of Researchers in Nigeria. Held in FCE (T), Gombe, 5-8 June.

[4]. Ali, A.(2000). Teacher production, utilization and turnover patterns in Nigeria. In kabir I: Anikweze, C.M; Alex, A.M; and Olokun, G.M. (Edited). Teacher production, Utilization and Turnover patterns in Nigeria. Kaduna; NCCE, P.1-9.

[5]. Apagu, V. V. (1997). Technical in-service competency needs of post primary school building technology teachers of Adamawa State. Unpublished Phd. Thesis; University of Nigeria, Nsukka.

[6]. Bamidele, I.R. (2002). Refocusing vocational technical education as an agent for positive economic change in $21^{\text {st }}$ century. In Sylverster O.O; Nwakolo, P.O.E; and Igborgbor G.C. (Edited). Refocusing Education in Nigeria: Benin; Da Sylva influence p.138.

[7]. Okoro, O .M. (2006). Principles and methods in vocational and technical education. Enugu: University Trust publishers.

[8]. Dirazo, D. K. (2000). Competency needs of technical teachers of Adamawa state. Nigeria Journal of Education and Technology. p. 25-30.

[9]. FGN/ Federal Republic of Nigeria, (2004). National policy on education. Lagos: NDRC

[10]. Haruna U.B (2012). Competency needs of basic technology teachers in Gombe State. A paper presented at the national conference organized by School of Education, F.C.E (T) Gombe, $9^{\text {th }}-11^{\text {th }}$ October.

[11]. Idris, A. (2006). Competency needs of metalwork teachers for effective teaching in post primary school in Gombe State. Unpublished M. Tech. thesis; Department of Science \& Technology Education. Moddibo Adama University of Technology, Yola.

[12]. Isah, M. P. and Abdulkadir, M. A. (2012). Achieving youth empowerment for national transformation through Technical Vocational Education and Training (TVET). Proceedings of the 25 th annual national conference organized by NATT. Held in Benue State University, Markurdi. p.131-135

[13]. Jadas, A.S. (1999). A follow-up study of bachelor of education (technology) graduates of Kaduna Polytechnic. Unpublished M. Ed. Thesis, Department of Vocational Teacher Education, U.N.N.

[14]. Kenenedy, O.O. (2011). Philosophical and sociological overview of vocational and technical education in Nigeria. American Eurasian Journal of Scientific Research,6 (1), 52-57.

[15]. NCCE, (2012). Minimum standard for colleges of education. Abuja: NCCE

[16]. Nuru, A.Y. (2002). Refocusing technical education in Nigeria. In Sylverster O.O; Nwakolo, P.O.E; and Igborgbor G.C. (Edited). Refocusing Education in Nigeria: Benin: Da Sylva Influence. P. 86-96.

[17]. Moureen, O. (2010). Nigeria! NCCE says teachers education curriculum has failed. Retrieved from http:// allafrica.com/stories/201009300584.html on 19/01/2013.

[18]. Ogwa, C. E. (2013). Effective technology and vocational education teacher training programmes: A panacea for national transformation. Proceedings of the $25^{\text {th }}$ annual national conference, organized by NATT. Held in Benue State University, Markurdi

Nigeria. p.11-17.

[19]. Okoro O.M. (2006). Principle and methods in vocational and technical education. Nsukka University trust publishers.

[20]. Olaitan, S. O. (1996). Vocational and technical education in Nigeria (Issues and Analysis). Onitsha, Nigeria:Noble Graphic Press.

[21]. Olukoya, O, (2014). Obj charges government on youth empowerment. Nigeria Tribune. Retrived from www.tribune.com.ng $13 / 08 / 2014$

[22]. Tafida I. and Abdulwahab, S. (2010). Human resource development and the challenges of quality of technical and vocational teachers in Nigeria. Journal of Vocational and Technical Educators (JOVTED) 2, (2), 100-108.

[23]. Udo, C. T. (2012). Training \& retraining of TVET teachers in technical colleges in the $21^{\text {st }}$ century. Proceeding of $25^{\text {th }}$ annual national conference organized by NATT in Benue State University, Markurdi. p. 268-272.

[24]. Victor, E.D. (2009). Technical and vocational education: Key to Nigeria's development Retrieved from http//www.nigeriavillagesquare.com html on 12/09/2012

[25]. World Bank (2011). Empowerment overview. Retrieved from http://go.worldbank.org/v45HD4P100, on 25/06/2013

[26]. YES, (2011). The YES! youth empowerment model definition. Retrieved from www.youthempowermentsolution.org/page_id=1758. 